\section{Í auga stormsins}

Pegar pessi grein er skrifuð, 22. mars 2020, eru liðnir 23 dagar frá fyrsta greinda COVID-19-smitinu hér á landi. Rétt rúmar prjár vikur. Pegar ég hugsa til baka finnst mér pað næstum ótrúlegt, pað virðist svo miklu lengra. Á pessum stutta tíma hefur orðið gjörbreyting á öllu umhverfi og fyrirkomulagi vinnu minnar sem heimilislæknir.

Sjálfsagt hafa orðið miklar breytingar hjá okkur öllum en par sem heimilislæknar, sem og heilsugæslan í heild sinni, er framvarðasveit heilbrigðiskerfisins skipti máli að bregðast við hratt, vel og fumlaust. Við ógn sem pessa erum við fyrstir inn og síðastir út. Við stöndum í auga stormsins. Viðbrögð við almannavá sem pessari eru einn af kjarnapáttum sérgreinar okkar og byggir stolt stéttarinnar á pví að standa pétt saman, bregðast hratt við og sinna verkinu sem best verður á kosið.

Pannig hefur heilsugæslan tekið hröðum breytingum undanfarnar vikur. Strax í upphafi vikunnar eftir fyrsta smit, 2. mars, tók heilsugæslan upp vitjanapjónustu vegna COVID-einkenna á dagvinnutíma. Pann 3. mars, fjórum dögum eftir fyrsta smit, hóf heilsugæslan sýnatökur fyrir utan allar heilsugæslustöðvar par sem sýni úr fólki í áhættuhópi var tekið gegnum bílgluggann. Sama dag hafði Læknavaktin tekið í notkun sérútbúinn bíl fyrir COVID-sýnatökur til viðbótar við venjulegan vaktbíl Læknavaktarinnar.

Viku seinna var öllum skjólstæðingum sem áttu bókaðan tíma boðið að fá símaviðtal í stað komu á stofu til að draga úr smithættu inni á heilsugæslustöðvum par sem stór hluti skjólstæðinga eru viðkvæmir fyrir. Ritarar hafa pannig hringt í hvern einasta bókaðan skjólstæðing og boðið peim að breyta tímanum. Vaktpjónustu var breytt úr opinni móttöku í fyrirfram bókaða tíma.

Pann 19. mars var móttöku Læknavaktarinnar skipt í tvennt, fólk með hita og öndunarfæraeinkenni annars vegar og fólk sem mætir af öðrum sökum hins vegar, til að bæta smitvarnir bæði lækna og skjólstæðinga. 22. mars hóf heilsugæslan sýnatökur um helgar og í næstu viku er áætlað að heilsugæslan sinni almennri vitjanapjónustu einnig á dagvinnutíma til að létta álagi af Læknavaktinni. Pá verður priðji vitjanabíll Læknavaktarinnar tekinn í notkun.

Á hverjum degi kemur inn fjöldi pósta um breytingar á vinnutilhögun - allt frá uppbyggingu vaktpjónustunnar, ungbarna- og mæðravernd og móttöku áhættuhópa niður í hvernig við getum skipt okkur í kaffitíma. Síðastliðna viku skiptist starfslið hverrar heilsugæslu í tvennt og vinnur helmingurinn í símaviðtölum heiman frá sér, viku í senn, til að draga úr hættu á að einstaka stöðvar lokist.

Símtalafjöldi til heilsugæslunnar og Læknavaktarinnar hefur margfaldast og ritarar taka við skráningum og upplýsingagjöf um sóttkví og einangrun. Allt petta bætist ofan á hefðbundna vinnu okkar sem ekki má tapast niður prátt fyrir önnur aðkallandi verkefni.

Síðustu vikur hefur oft komið upp í huga mér pað sem ég hef heyrt ítrekað síðan ég byrjaði í læknadeild:

Heilbrigðiskerfið er eins og olíuskip, pað tekur langan tíma að beygja út af fyrri stefnu.

Ég held pað hljóti hér með að vera afsannað.

Ég sé ekki betur en einmitt núna hafi heilbrigðiskerfið gjörbylt starfsemi sinni á mettíma. Pegar ákvarðanir hafa verið teknar eru pær tilkynntar strax og breytingar framkvæmdar um leið. Sem dæmi má nefna útvíkkun á sýnatökum óháð áhættusvæðum í Evrópu sem tilkynntar voru á blaðamannafundi kl. 14. Strax á síðdegisvakt premur tímum síðar hafði verið brugðist við. Eftir hádegi síðastliðinn föstudag var ákveðið að hefja sýnatökur um helgar. Á sunnudegi var starfslið frá Heilsugæslunni í Efra-Breiðholti mætt í bílakjallarann í Hörpunni og tók um 100 sýni.

Breytingar hafa verið gerðar ótrúlega fumlaust og án mótmæla par sem allir hafa unnið sem einn maður til að takast á við núverandi ástandi. Gamalgróinn rígur milli undirsérgreina hefur horfið og teymisvinna heilbrigðisstétta hefur tekið á sig allt annan blæ, par sem hver léttir undir með öðrum og allir hjálpast að við að breyta og bæta pjónustuna eins og hægt er.

prátt fyrir yfirpyrmandi álag og áreiti hefur andinn milli starfsmanna á minni heilsugæslu sjaldan verið betri.

Раð hefur verið stagast á pví í fréttum undanfarið að nú lifum við fordæmislausa tíma. Рað má vera satt. En ég held við ættum frekar að líta á pá sem fordæmisgefandi tíma. Fordæmisgefandi fyrir hversu vel við getum unnið saman sem ein heild, fyrir hversu hratt og vel við getum breytt, bætt og aðlagað vinnu okkar að pví sem upp kemur - og umfram allt hversu öflug við raunverulega erum pegar á reynir.

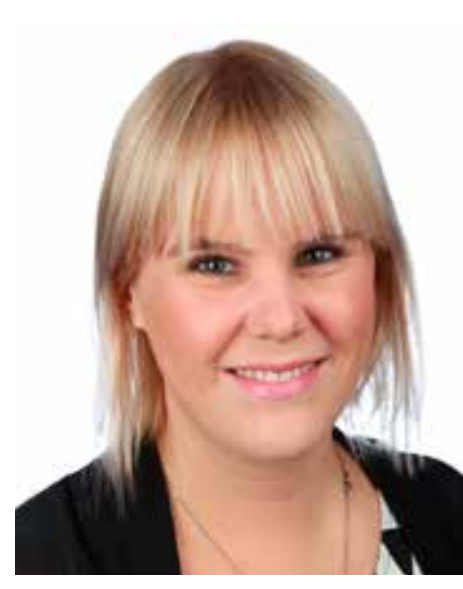

\section{Margrét Ólafía Tómasdóttir}

heimilislæknir við heilsugæsluna Efstaleiti og lektor í heimilislækningum við læknadeild HÍ

Margrét situr í ritstjórn Læknablaðsins

margretolafia@gmail.com

\section{In the eye of the storm}

Margrét Ólafía Tómasdóttir MD, PhD, Family Physician at the General Health Care of the Capital Area and Assistant Professor in Family Medicine at the University of Iceland.

DOI: 10.17992/lbl.2020.04.574 